\title{
Sustainable Management in Agriculture
}

\section{Natalia Rastorgueva}

Sapienza University of Rome

\section{Doi:10.5901/ajis.2013.v2n8p486}

\section{Abstract}

In the modern economy, sustainable development of enterprises is impossible without effective sustainable management, which is extremely important for the development of agricultural enterprisers. Nevetheless, the issues of the environmental performance are also essential, because reducing the environmental impact of the production is increasingly necessary in today's world.Initially, this article describes the theoretical aspects, concepts and examples of interaction between the sustainable management, the environmental performance and sustainable supply chain management.Hereafter, in the article was investigated the practice of sustainable management used in the huge and small rural european enterprises and with the SWOT-analysis compared the approaches of their application.

\section{Intoduction}

Sustainable development necessary for all sectors of the economy, especially in the underdeveloped regions, such as the countryside. Precisely the rural areas with the lack of high developed industry needs the sustainable agricultural production and economical development, which can reduce the number of hungry people and alleviate rural poverty. The tool for sustainable development is sustainable management, its components are discussed below.

Research question of this article: which factors (leverages) are essential for the success of agricultural sustainable management?

\section{Methodology}

There were conducted interviews with managers of the different sizes agricultural enterprises about sustainability issues. Then, based on the literature review and interviews data, it was conducted the SWOT-analysis of the practices applying sustainable management.

\section{Literature browse}

Agriculture, farming and food production are essential elements of the economy in every society. In terms of indirect effects, any significant cut back in European farming activity would in turn generate losses in GDP and jobs in linked economic sectors - notably within the agri-food supply chain, which relies on the EU primary agricultural sector for high quality, competitive and reliable raw material inputs, as well as in non-food sectors. (CAP http://eur-lex.europa.eu).

The main contribution of the CAP - a territorially and environmentally balanced EU agriculture within an open economic environment. In other words, the directions of the CAP there are: developing rural areas and farming simultaneously taking care of the environment and long-term food security (CAP http://eur-lex.europa.eu).

As an integral part of the CAP, rural development policy has proved its value by reinforcing the sustainability of the EU's farm sector and rural areas - economically, environmentally and socially (CAP http://eur-lex.europa.eu).

Sustainability - is very wide and multi-pronged economic category that affects almost all aspects of activity and functioning of the enterprise.

Hendriques and Richardson consider, in generally, two main kinds of approach to sustainability: 'top down' and 'inside out'. Top down approach emphasize management measurement and control. Inside out approach stress the importance of change and innovation (Hendriques, Richardson, 2004). Nevertheless in agriculture for achieving sustainable development is necessary to combine both this approaches.

The core concept of sustainability as an contemporary economic category, is a classical symbol TBL (Triple Bottom Line), coined by J. Elkington, integrates the key components of sustainability. Because, the interaction of 3 important aspects (economy, social, environment, or people, profit, planet) has the effect of sustainable development. 
These three components anyway evident in modern relevant literature in the discussion the sustainability and path for its accomplishment.

Achieving sustainability is a complex process that requires attending to issues such as resource depletion, waste generation, population growth, species diversity, sociocultural diversity, social justice, economic justice, environmental justice, and aesthetic beauty (Gladwin, Kennelly and Krause 1995).

The MAFF (UK Ministry of Agriculture, Forestry and Fisheries) defines sustainable agriculture as:

1. ensuring the continuing availability to the consumer of adequate supplies of wholesome, varied and reasonably-priced food, produced in accordance with generally accepted environmental and social standards;

2. maintaining a competitive and flexible industry which contributes to an economically viable rural society;

3. ensuring effective protection of the environment and prudent use of natural resources;

4. conserving and enhancing the landscape, wildlife, cultural and archaeological value of agricultural land;

5. respecting a high level of animal welfare (MAFF, 2002).

According to Warhurst sustainability indicators collected in Tab. 1

Table 1. Groups of indicators (Sourse: Warhurst, 2002)

\begin{tabular}{|c|c|c|}
\hline \multicolumn{3}{|l|}{ Sustainability } \\
\hline environmental & economic & social \\
\hline $\begin{array}{l}\text { Natural resource protection; } \\
\text { Environmental strategy; } \\
\text { Management of local environmental } \\
\text { impact }\end{array}$ & $\begin{array}{l}\text { Sustainable economic } \\
\text { perfomans; } \\
\text { Economic impact of the industry; } \\
\text { Employment impacts of the industry }\end{array}$ & $\begin{array}{l}\text { Internal stakeholder relations; } \\
\text { External stakeholder relations }\end{array}$ \\
\hline
\end{tabular}

The current EU development policy is based on three separate axes:

- improving the competitiveness of the agricultural and forestry sector;

- improving the environment and the countryside;

- improving the quality of life in rural areas and encouraging diversification of the rural economy (http/lec.europa.eu/agriculture/rurdev/index_en.htm).

According to FAO, sustainability - it is a multi-dimensional concept encompassing environmental integrity, social well-being, economic resilience and good governance (Tab.2): each dimension involves several issues and all dimensions need to be considered. Sustainability is an ambitious objective that can be reached through different pathways (FAO, 2013).

Table 2. Sustainability dimensions (Sourse: FAO 2013)

\begin{tabular}{|c|c|c|c|}
\hline Governance & Social & Environment & Economy \\
\hline $\begin{array}{l}\text { holistic management; } \\
\text { governance structure } \\
\text { rule of low; } \\
\text { accountability; } \\
\text { participation }\end{array}$ & $\begin{array}{l}\text { cultural diversity; } \\
\text { equity; } \\
\text { human health and safety; } \\
\text { labour rights; } \\
\text { decent livehood }\end{array}$ & $\begin{array}{l}\text { atmosphere; } \\
\text { water; } \\
\text { land; } \\
\text { materials and energy; } \\
\text { biodiversity; } \\
\text { animal welfare }\end{array}$ & $\begin{array}{l}\text { investments; } \\
\text { vulnerability; } \\
\text { local economy; } \\
\text { product safety and quality }\end{array}$ \\
\hline
\end{tabular}

Other issues of sustainable development there are risk management and diversification of activities.

Many authors inclined to think that different types of diversification of rural economy or farmers non-agricultural activities (such as rural tourism, provision of leisure services and so on) provide benefit, improve the competitiveness, environment and quality of life in rural areas (De-Magistris, Dries, Pascucci, Gardenbroek, 2012).

Applying sustainability in organizations means implementing sustainable strategic management systems that provide economically beneficial ways for organizations to effectively incorporate the environmental, social and cultural complexities of sustainability into their strategic decision-making process (IEBM vol.2).

At the micro level, environmental and social aspects of TBL are reflected in the CSR (Corporate Social Responsibility) policy of rural enterprisers. 
Experience of some huge international agricultural companies can use as a very good example illustrating successful practice of sustainable management.

Reducing environmental impact and tackling the complex economic and social challenges are the the main directions CSR such companies.

Their sustainability is achieved using the wide diversification of the agricultural production, high quality and risk management. And considering a high level of economic profitability is given great attention to the environmental and social aspects.

And return to the above TBL, the interaction of the three components of sustainability in this case is showed on Fig.1:

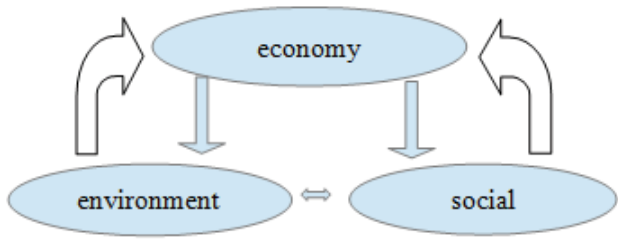

Fig. 1. Interaction sustainability categories

In general terms, agricultural sustainable management should be consider together with its components and should be based on it (Fig.2)

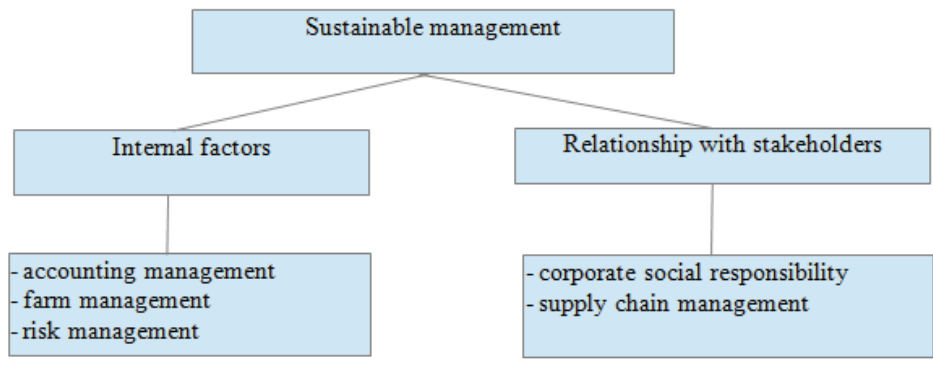

Fig 2. Interconnections between the different types of management

Source: authors elaboration

Effective farm management - the basis of rural sustainable development.

According the CAP, the EU has some 14 million farmers with a further 4 million people working in the food sector. The farming and food sectors together provide $7 \%$ of all jobs and generate $6 \%$ of European gross domestic product (CAP).

Farm management as considered here is a professional discipline which relates to the description, construction, analysis and evaluation of farm systems. Farm management as carried out by farmers has been defined (Dillon 1980) as 'the process by which resources and situations are manipulated by the farm manager in trying, with less than full information, to achieve his [or her] goals'.

Farm management - it is not only the correct application specific techniques (soil analysis, seed selection, animal breeding ect.). According to FAO, farm management is the science (and art) of optimizing the use of resources in the farm component of farm-households. Decisions in farm management must then be made using economic analysis based on non-money values, intuition and judgement. And in yet other cases, such as assessing the resource sustainability and environmental compatibility of alternative farm systems, it may often be infeasible to impute money values to the gains and losses of alternative choices.

Obviously other farm and family-related disciplines will be involved in systems' construction: agronomy, animal husbandry, soil and water conservation/management, human nutrition etc. Nevertheless, economics is the disciplinary 
basis of farm management. And the most important for small traditional farms are sociology and social anthropology (FAO). However, crucial external factor for every kind of farm enterprises is supply chain management, because farmers receive the income after selling their products.

International Encyclopedia of Business and Management (IEBM) defines a supply chain as a set of suppliers of and their suppliers, and costumers and their costumers, and the physical and information flows which link them together. The concept of a supply chain brings together insights and notions from a number of related sources - purchasing, physical distribution systems, logistics, industrial marketing, information systems and technology, and inventory management to name a few (IEBM 2002).

And consequently, supply chain management - the management of a complex system with its complex of suppliers, costumers, physical and information flows, and issues of geography, ownership and control (IEBM 2002).

There are a multitude of mechanisms that are important in supply-chain management in agriculture. These include varying forms of hedging and cross-hedging, use of contracting mechanisms, geographic diversification and use of buffer stocks. I other words, geographic diversification is a relevant strategy for supply-chain management.

The traditional means of managing risks in the supply chain is hedging. Risk management lets manage risks related to quantity, quality, price risk, as well as logistical risks including risks in modal arrivals, transit times, etc. (Wilson 2010).

Increased consumption of biofuels from 954,280.6 (2000) to 1,132,462.3 (2009) kt of oil equivalent (according to FAOSTAT) in all over the world indicates about environmental rural development. Another example of eco-efficient rural activity is farm organic.

Organic agriculture is a production management system that aims to promote and enhance ecosystem health, including biological cycles and soil biological activity (FAO). 38 million hectares of land were organically farmed in 2009. Organic area rose by almost 30 percent in the second half of the last decade (FAO-FiBL-IFOAM)

Organic farm - one of the intensively developing eco-friendly activities in agriculture, despite its cost and restrictions that must be observed during the producing process. Nevertheless, not all rural enterprises can follow restrictions for organic production, because its extremely decrease productivity.

Specialists of rural enterprises are also paying attention accountability. Because it enables efficiently manage the rural enterprise and solve arising problems. In some cases, providing sustainability - is the executing of the developed plan and risk management, as well as daily monitoring of the production process. Control and managing in rural enterprisers is carried through the collection and processing of data.

The importance of the accountability is written by Hendriques and Richardson, they assert, that shareholders and government will be interested in economic issues. It is therefore not appropriate to confine accountability to the social dimension of sustainability. So, in relation to the nature of corporate activity, accountability is an integral part of the process of implementing all aspects of sustainability. It is also true that the way in which accountability may be discharged is similar, whatever the sphere of accountability (Hendriques, Richardson).

Below (Tab. 3) is SWOT-analysis of the applying sustainable management practices, which show different factors affecting the sustainable rural enterprise.

Table 3. SWOT-analysis of the applying sustainable management practices

\begin{tabular}{|c|c|c|}
\hline \multirow[t]{2}{*}{ Internal } & Strenghts & Weakness \\
\hline & $\begin{array}{l}\text { - biodiversity -reduces impact of seasonality and allows to } \\
\text { receive income during the year; } \\
\text { - sufficient level of financial stability (needed for investment } \\
\text { and loan) }\end{array}$ & $\begin{array}{l}\text { - expenditures for social projects (are very } \\
\text { expensive); } \\
\text { - unskilled staff }\end{array}$ \\
\hline \multirow[t]{2}{*}{ External } & Opportunities & Threats \\
\hline & $\begin{array}{l}\text { - competitiveness; } \\
\text { - the opening of new rural markets; } \\
\text { - reputation of the enterprise; } \\
\text { - reducing environmental impact }\end{array}$ & $\begin{array}{l}\text { - reducing the prices for farm products; } \\
\text { - unfavorable weather conditions; } \\
\text { - public policy change (reduction of subsidies, } \\
\text { taxation percentage increasing) }\end{array}$ \\
\hline
\end{tabular}




\section{Conclusions}

Agricultural sustainability and sustainable management - the categories described in the current scientific literature repeatedly. After coined TBL in the middle of 1990-th, definition of the sustainability had become more specific.

In order to achieve a sufficient level of rural sustainability at farm enterprises needed the holistic systems approach, which consider internal and external influent factors.

From a theoretical and practical point of view, which is shared by scientists and managers, using the internal potential such as different types of diversification in rural enterprises - is one of the main pathways to achieve the sustainability in farm management, and the quality and competitiveness of agricultural products.

\section{Limitations}

In the end there are some limitations in the paper. Firstly, this is theoretical review article, because, considering the differences in standards of living and levels of rural development in the different countries of the European Union, it is impossible to establish a specific framework for determining the sustainability. Secondly, indicators of financial stability, accountancy, the amount of environmental payments to and social programs in many enterprises are confidential information, which complicates the conducting a detailed comparative analysis of the agricultural sustainability.

\section{Acknowledgment}

This article is supported by the Erasmus Mundus Action 2 Programm of European Union.

\section{References}

Pacini C., Lazzerini G., Migliorini P. And Vazzana C. (2009): An indicator-based framework to evaluate sustainability of farming systems: review of applications in Tuscany. Italian Journal of Agronomy, 4 (1): 23-40 ISSN:1125-4718

Dries L., Pascucci S., Gardenbroek C. (2012) Diversification in Italian systems: Are farmers using interlinked strategies? New Medit. Vol.XI. - n.4 - dicembre 2012.

Pascucci S., De-Magistris T., Factors affecting farmers' likehood to use advisory and extension services. New Medit. Vol.XI. - n.3 settembre 2012.

The New Palgrave Dictionary of Economics edited by John Eatwell, Murray Milgate, Peter Newman. Vol. 1. Macmillan Press Limited 1987

Warren, G.F. 1913 Farm Management. New York: Macmillian

Taylor, H. C. and Taylor A. D. 1952 The story of Agricultural Economics. Ames, lowa: lowa State University Press

The Common Agricultural Policy partnership between Europe and Farmers. European Commission. Directorate-General Agriculture and Rural Development. 2012. http://ec.europa.eu/agriculture/50-years-of-cap/index_en.htm

International Encyclopedia of Business and Management (IEBM) 2nd edition 2002 Edited by Malcolm Warner. Vol. 7

Towards sustainabily agriculture: A pilot set of indicators, MAFF (February, 2002) http://www.adlib.ac.uk/resources /000/015/650/pilotindicators.pdf

Warhurst Alyson. Mining and Energy research Network Promoting Corporate Citizenship and Sustainable Development. Sustainability indicators \& Sustainability perfomance management, Paris, 2002 pubs.iied.org

H. Wattenbach and K.H. Friedrich, Agricultural Support Systems Division,1997 Farming systems indicators for sustainable natural resource management, FAO, Rome, Italy

The Triple Bottom Line: Does it All Add Up? Assessing the Sustainability of Businessand CSR/ editors Adrian Hendriques, Julie Richardson. 2004 Earthscan, London

Wilson William. Envovlving Agricultural Supply Chains 2010. Farming, Finance and the Global Market place. Jine 8-10, 2010. Kansas City, Missouri. (http://www.kc.frb.org/publicat/rscp/session-3-ag-supply-chains.pdf)

Dillon, J. L. (1980), The Definition Of Farm Management. Journal of Agricultural Economics, 31: 257-258. doi: 10.1111/j.14779552.1980.tb01516.x 